\title{
Educating smart materials
}

\section{Kretzer, Zurich Manuel}

Resumen: Nuestro entorno diario está claramente ocupado por las tecnologías digitales, que influyen en la forma en que nos comportamos, nos movemos o interactuamos unos con otros. Para que los arquitectos puedan mantenerse al día con el progreso tecnológico continuo y estar preparados para los próximos desafíos e incertidumbres, necesitan ser capacitados en el uso de nuevas tecnologías y poseer habilidades en el intercambio interdisciplinario.

Especialmente con respecto a la aplicación de nuevos materiales, que a menudo provienen de áreas como ciencia de los materiales, la biología o la química, los arquitectos no sólo necesitan una comprensión de las distinciones específicas de la

Cuadernos del Centro de Estudios de Diseño y Comunicación №70

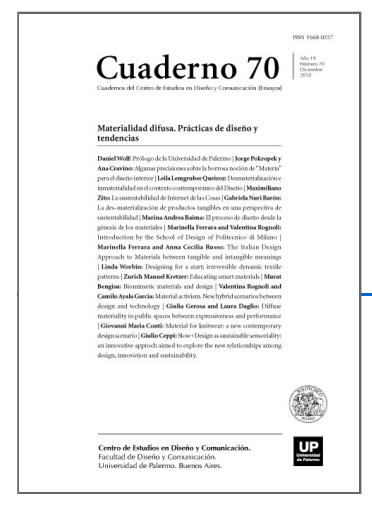

ISSN: $1668-0227$

Materialidad difusa.

Prácticas de diseño y

tendencias

Año XIX, Diciembre 2018, Buenos Aires, Argentina | 172 páginas

descargar PDF ver índice de la publicación

Ver todos los libros de la publicación

compartir en Facebook

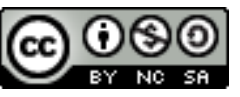

Esta obra está bajo una Licencia Creative Commons Atribución-NoComercialCompartirlgual 4.0 Internacional disciplina, sino especialmente estar familiarizados con una forma de expresión compartida. El siguiente artículo presenta un modelo didáctico para la educación integradora y exploratoria de materiales inteligentes como un medio para enriquecer los marcos educativos existentes. Sin embargo, en vez de prescribir un método particular o una solución predefinida, el enfoque pretende proporcionar un acceso abierto a la información y sugerir una amplia gama de posibilidades relevantes. Por lo tanto, a los estudiantes no se les enseña "qué hacer" sino que se les anima a aprender "cómo hacer" ofreciendo un marco estable y rico para el autodesarrollo independiente.

Palabras clave: Educación - Alfabetización - Materiales inteligentes - Arquitectura adaptable - Fabricación, Bricolaje - Open Source.

$\left(^{*}\right)$ Dr. Sc. ETH. Architect, researcher and educator. He is currently visiting professor at the Braunschweig University of Art, leading and teaching the subject 'Digital Crafting'. Manuel is the founder of the 'materiability research network', an educational platform that provides open access to cutting edge new material developments and technologies.

Introduction 
Science and technology multiply around us. To an increasing extent they dictate thelanguages in which we speak and think. Either we use those languages, or we remain mute.J. G. Ballard, Crash, 1974

Digital technologies nowadays infiltrate, and to some extent even dominate, almost every aspect of human life. Just as such progress constantly influences our environment, behavior, and culture it does have an undeniable impact on architecture and the way space is used and perceived. In order to keep up with continuous technological advancement and be skillful in its spatial integration, the role and proficiency of the architect has to steadily evolve. This means especially for architectural education to efficiently prepare students for upcoming challenges and uncertainties. While this involves the theoretical and philosophical discussion of current tendencies, beliefs, and developments it also demands the training of practical skills and powers, such as the use of new tools, technologies, and materials but especially capabilities in interdisciplinary communication and exchange. Cliff Moser, author of Architecture 3.0 - The Disruptive Design Practice Handbook, argues that architectural education today is too much concentrated on growing experts in 'design for building', which leads to isolated and overspecialized individuals. Instead architecture schools should show students how to think broadly and develop design "solutions leveraged with collaboration and networking". (Moser, 2014)

Similarly Nic Clear, head of architecture and landscape at the University of Greenwich, believes that multi- and interdisciplinary ways of working are essential to acquire an open understanding of collective power to overcome the old-fashioned idea of the architect representing the one and only lead expert. At the core of interdisciplinary progress is however not only a non-hierarchic structure and a common curiosity in approaching a shared goal but especially the ability of all involved parties to successfully communicate and converse. This becomes even more evident when areas like materials science, biology, or chemistry, the birthplaces of many newly emerging materials, are involved in the discussion. These areas are not only accustomed to very particular means of representation and the use of specialist language but for example also have a fundamentally different idea of scale and efficiency. Thus for architects to successfully collaborate with such areas for the development of new, technology-enhanced spatial experiences they not only need an understanding of discipline-specific distinctions but especially be literate in a shared way of expression.

The inherent dynamics of smart materials

As Jeffrey Karl Ochsner notes, all materials are inherently dynamic, continuously shrinking, expanding, moving and changing, yet largely in a non-directly perceivable way (Ochsner, 2012). Smart or adaptive materials however, materials which can adjust their properties in response to external influences, are fundamentally distinct from traditional materials and therefore need to be approached in a very different way. Such materials can change their color in response to changes in temperature or UV radiation, they can adjust their transparency, light up or move through electricity, they can store heat and energy, they can convert sunlight, heat or mechanical distortion into electrical power or even have the ability to self-heal and repair. For the development of dynamic architectural solutions such materials have great potential and many advantages over existing, mechanically complex systems not only due to their dynamic properties but especially because of their inherently holistic setup. Yet in order to apply them progressively it is necessary to understand their behavior over time and evaluate the range within which they perform. This requires knowledge in their transformative capabilities as well as a general idea of their internal processes and composition. One option to gain such understanding is to break the materials down into their normative ingredients, explore the properties of these ingredients, and then put them back together. Through this one comprehends how changes in assembly relate to particular material properties or 
behaviors, which then can be tuned to special demands or requirements that vary from commercially available products. At the core of this idea is not the development of a specific expertise or the improvement of existing systems but rather the mediation of a basic notion of certain principles necessary to communicate and exchange with specialists from the various disciplines. Such exchange might then stimulate the discovery of formerly unknown applications or even incept the development of new materials.

A possible way to approach this is by starting with a brief (online) search into new material discoveries or developments. This search can relate to certain material phenomena such as color-change, movement, lightemittance, energy conversion etc. or focus on novelty and recent discoveries. Once a particular material has been found it needs to be understood in more detail by studying scientific papers, technical articles, or other related information. When a basic theoretical knowledge of the material's working principle, composition, and fabrication has been acquired, experts can be approached to receive more specific details. This can involve gaining first-hand insights in (industrial) production procedures, solving or improving certain assembly issues, understanding trends in commercial application, or even collaborating throughout the course of a project and especially during an introductory expert workshop. The next step involves acquiring the necessary ingredients and tools to build the material. Once again expert support can help in finding the right sources. A particularly difficult part is to estimate the required quantities since usually the ingredients are quite expensive and therefore purchasing too much will result in high costs, but having too little might unnecessarily delay the progress of the work. Generally ten to twenty percent above the calculated estimate provide for good contingency. In some cases it might also make sense to look for ready-made kits, which allow for the manufacture of a certain set of prototypes and which usually also come with wellexplained instructions. As soon as all the necessary tools and substrates are at hand one can begin building the first samples. What should always be remembered is that failure and breakage are essential elements of the process. Once one feels confident enough in making a working material, this knowledge can either be used to continue experimenting more focused, aiming for example at emphasizing a certain effect, or become the basis to start teaching others. In the case of a course or workshop for students of architecture the participants should be divided into small teams of three to four people. While physically experiencing the functionality of the materials, comprehending their working principles, and the relationship between fabrication procedures and material behavior they can in parallel be asked to speculate about architectural situations in relation to a specific theme. In the beginning the correlation between the material and hypothetical usage can be very loose but should be intensified towards the end of the course. Lectures on related topics, selected literature, as well as a collection of case studies support the students to get started within a commonly unknown field. Throughout this part they should be encouraged to relate to spaces in terms of dynamic territories, considering architecture not as being static and immobile but as an assembly of places that constantly evolve and change in relation to time and occupancy. Finally the two approaches, the material exploration and the architectural scenario, can be brought together through a spatial installation or prototype. The relation to reality and presence is depending on the theme of the course, however leaving it to the students can lead to unexpected and surprisingly entertaining results. (Figure 1)

While this approach definitely makes for a lot of fun among workshop participants and will provide them with useful skills in respect to a particular material it is impossible to go through such an intense process for every smart material available. Therefore a more general strategy is required.

The materiability research network: access to smart materials 
Common ways for the conveyance of material knowledge include libraries, catalogs, and databases, both physical, in print, and virtual. Within these, materials are generally sorted and categorized in relation to certain similarities. In print this is often based on either their dominant material class or other defining properties. Physical libraries employ similar means of categorization but also place a specific focus on size, appearance, and possibly usage of the samples on display. Online databases offer more flexibility since their contents can be sorted dynamically according to relevant taxonomies but sometimes seem less detailed and more superficial. In respect to traditional materials such types of categorization in combination with a two-dimensional representation through photographs and technical drawings work quite well. Especially when having a technical background one can anticipate how a material feels or behaves simply by looking at it or reading about its properties. Regarding smart materials however, which are much less known and available, it is far more difficult to forecast their usage.

An attempt to make these materials more commonly available is the materiability research network (www.materiablity.com), a community platform, an educational network, and an open materials database that provides in-depth access to emerging material developments. The aim of the network, which was instigated in 2012, is to demystify smart materials and reveal their complexity while fostering inter-disciplinary exchange and cooperation. The website forms a constantly growing database on a broad range of materials, provides do-ityourself instructions to self-make them, and promotes their usage in speculative spatial explorations. This trinity, inspiration, information, and instructions is ought to help advance a common language to communicate across disciplines and bridge the gap between research, education, and practice.

Registration to the network is free of charge and allows members to unlimitedly access all provided information, converse with fellow members, engage in forum discussions, and submit their own projects or experiments. The content is split into three areas: 'projects,' 'materials,' and 'tutorials.' 'Projects' are openly accessible and focus on innovative and inspirational usage of smart materials in an architecture or design context. They can be sorted according to rating, views, and age, as well as several tags, such as material class, creative discipline, scale, phenomenological behavior, or physical and optical properties. 'Materials' and 'Tutorials' are only visible to active members of the network, who are registered and logged-in. The information on materials is intended to present a scientifically funded context, providing in-depth but easily understandable details on particular smart materials. The graphically illustrated posts are usually split into a short introduction, an excerpt on the material's historical development and usage, an explanation of its structure and operation principle, a brief description of its fabrication, and an overview of existing and potential (architectural) applications. In addition to this theoretical material information, tutorials are offered, which are often developed in junction or with the help of specialists from the respective fields. Each tutorial follows a similar structure and provides both photographic and text-based step-by-step instructions to self-make the material in an informal environment.

To further promote exchange and collaboration among the steadily growing community, the network provides an internal messaging service, allowing members to directly contact each other. Persons who have connected in this way will appear on each other's profile page as 'friends.' The profile page, which is only visible to logged-in members, also displays a user's personal information and latest network activity, like posts, comments, and forum topics and replies. The materiability research network thus not only represents a website that delivers information on smart materials, but also encourages its users to get actively involved in its future development. Becoming a member of the network means to identify oneself with the content and become part of the community. By publishing information on the platform users have to take responsibility for their work and review and expose it within the larger context. This means that they have to be aware of the information they consume 
but also the content they produce and its further impact. The aim of the network is to provide a community-driven, growing overview of smart materials in an architecture and design context, while encouraging its members to exchange and critically reflect upon their potential usage. (Figure 2)

Towards a smart material literacy

The hope is that through these two approaches, the physical experience of smart materials during associated workshops and the potentially unlimited access to similarly comprehensive information on the website, it will eventually become possible to anticipate the functionality, behavior, and usage of any type of smart material without necessarily requiring a working prototype, just as one, with a little experience in craftsmanship, doesn't require to touch a piece of wood in order to know how it feels, looks, or what it can be used for.

This will eventually free smart materials from persistent associations to mechanically infused paradigms, which to date still mark the main form of describing dynamics, movement, and behavior. The herein presented approach as a didactic model has been tested and verified throughout numerous workshops and student courses. Despite its brevity of a little more than five years it can so far be considered a largely successful method to engage students in exploring new territories and encourage them to think in terms of processes rather than fixed states, yet it obviously always needs to be adapted to the respective context and situation. Especially the display of dynamic behaviors still requires further investigation and will need the development and acceptance of good alternatives to established means of architectural representation such as plans and models. One possibility would be to shift the focus towards working demonstrators and physical prototypes instead of their graphical display. Another option is to draw inspiration from the Internet and online visualizations, which allow the seamless combination of video, audio, image, and text based content.

As mentioned earlier the impact of these materials on architecture could be massive not only leading to dynamic and adaptive spaces but also more efficient and much lighter, less material intense structures. Yet in order to arrive there a number of elementary challenges need to be overcome. Firstly a serious awareness among material-related fields in regards to architectural possibilities has to be created and then multi-disciplinary collectives should be formed to progress the development of materials tailored for architectural usage. It is important to immerse oneself into such collaboration unbiased, driven by curiosity and not oppressed by thinking in terms of limitations, be it scale, durability, affordance or even resources. Instead constant technological progress should be seen as an opportunity, which allows daring and experimenting and which eventually will make any kind of development increasingly cheaper and available. But even more importantly the focus should move beyond concentrating purely on the functionality and efficiency of smart materials and the advantages they have over existing systems but equally consider their emotive aspects and the more sublime impact they have on human senses. Engaging in possibilities and implications rather than the actual effects will hence become crucial to develop truly revolutionary products, spaces, or experiences. (Figure 3)

\section{References}

Ballard, J. G. (1995). Crash. London: Vintage, 7.

Moser, C. (2014). Architecture 3.0: The Disruptive Design Practice Handbook. New York: Routledge, 15-17. 
Ochsner, J. K. (2012). Furniture Studio: Materials, Craft, and Architecture. Seattle: University of Washington Press, 6.

Abstract: Our daily environment is clearly occupied by digital technologies, which influence the way we behave, move, or interact with one another. In order for architects to keep up with continuous technological advancement and be prepared for upcoming challenges and uncertainties they need to be educated in the use of new technologies and possess skills in interdisciplinary exchange. Especially in respect to the application of new materials, which often stem from areas like materials science, biology, or chemistry, architects not only need an understanding of discipline-specific distinctions but especially be literate in a shared way of expression. The following article presents a didactic model for integrative and explorative smart material education as a means to enrich existing educational frameworks. Yet rather than prescribing a particular method or predefined solution the focus of this idea is on providing open access to information and suggest a broad range of relevant possibilities. The students are thus not taught "what-to-do" but instead encouraged to learn "how-to-do" by offering a stable and rich framework for independent self-development.

Key words: Education - Literacy - Smart Materials - Adaptive Architecture - Fabrication - DIY - Open Source.

Resumo: O nosso ambiente diário é claramente ocupado pelas tecnologias digitais que influenciam a forma como nos comportamos, nos movemos e interagimos uns com os outros. Para que os arquitetos possam acompanhar o progresso tecnológico contínuo e estar preparados para os próximos desafios e incertezas, precisam ser treinados no uso de novas tecnologias e possuem habilidades interdisciplinares. Especialmente no que diz respeito à aplicação de novos materiais, que muitas vezes vêm de áreas como a ciência dos materiais, biologia ou química, os arquitetos devem ter não só uma compreensão das diferenças específicas de a disciplina, mas principalmente estar familiarizados com uma forma de expressão compartilhada.

O artigo apresenta um modelo didático para a educação integradora e exploratória dos materiais inteligentes como um meio para enriquecer estruturas educacionais existentes. No entanto, em vez de prescrever um determinado método ou uma solução pré-definida, a abordagem pretende proporcionar acesso aberto à informação e sugerir uma ampla gama de possibilidades relevantes. Portanto, os alunos não são ensinados a "o que fazer", mas são incentivados a aprender "como fazer", proporcionando um quadro estável e rico para o autodesenvolvimento.

Palavras chave: educação - alfabetização - materiais inteligentes - arquitetura adaptativa - fabricação - Home Improvement - Open Source.

Educating smart materials fue publicado de la página 89 a página96 en Cuadernos del Centro de Estudios de Diseño y Comunicación Nº70 